DOI: https://doi.org/10.24297/ijmit.v15i.8888

\title{
The Mediation effect of Value-Co-Creation on Customer Engagement and Positive E-WOM
}

\author{
Salwa Fouad Taher ${ }^{1}$, Dr. Mahmoud Abdulhamid Saleh ${ }^{2}$ \\ ${ }^{1}$ Lecturer and Ph.D. student. Marketing Department, King Saud University, Saudi Arabia \\ 2 Professor. Marketing Department, King Saud University, Saudi Arabia \\ ${ }^{1}$ staher1@ksu.edu.sa ${ }^{2}$ mahsaleh@ksu.edu.sa
}

\begin{abstract}
The current study investigates the mediation effect of value-co-creation on customer engagement and positive e-WOM in a competitive Saudi Arabian market. An attempt to illustrate the factors influencing the positive eWOM as a result of changing customer's interests and lifestyle. The engagement of consumers in the co-creation of value is powerful in understanding consumer behavior. The paper has made an applied attempt in the Saudi Arabian market to study customer engagement, value co-creation, and positive e-WOM, which adds to the knowledge line in the digital marketing discipline.
\end{abstract}

Keywords: Customer Engagement, Value-Co-Creation, Positive E-WOM, Enthusiasm, Participation, and Social Interaction

\section{Introduction}

Costumers nowadays are interacting and communicating through different social media platforms; their role has developed from being receivers to becoming information co-creators (Jahn \& Kunz, 2012). This interaction is viewed as consumer engagement. Marketing Science Institute (MSI, 2008) considered customer engagement as one of the priority research subjects in the present-day marketing field. Research shows that highly engaged customers on the social platform play an important role in generating contents, referring products, services, and brands to other customers, and co-creating customer experience and value (Jaakkola \& Alexander, 2014; Hajli et al. 2014). According to Prahalad and Ramaswamy (2004a, b), the value of a product or a service is not created solely by the organizations but by both organizations and the consumers. Social media platforms have a great timeliness and influence because of its viral spread of information through consumers (Kaplan \& Haenlein, 2010). Therefore, it can be argued that social media can serve as an effective platform for organizations to make use of customers' social networks communications in spreading information instantly to a large number of potential customers.

The present study intends to find the mediation effect of value-co-creation of customer engagement and positive e-WOM in a competitive Saudi Arabian market. The research will propose a conceptual model to conduct an empirical study of the influence of customer engagement on value co-creation and e-WOM, and to test the mediating role of value co-creation. It is expected that the study can provide evidence that will help organizations to better understand the importance of customer engagement on social media and e-WOM. The explanations of the results will provide guidelines on how organizations can encourage consumers to engage and communicate through different social media platforms in order to influence positive e-WOM. It is also expected that the study can enrich previous research on customer engagement, value co-creation, and e-WOM in the Saudi business environment.

\section{Literature Review}

\subsection{Customer Engagement}

Customer engagement is considered as a new important concept in marketing (Zhang, M., Guo, L., Hu, M., \& Liu, W., 2017). Researches that were conducted on customer engagement mostly focused on the definition of the concept and the development of the scale (e.g. Jaakkola \& Alexander, 2014; Hollebeek, Glynn, \& Brodie, 2014). Patterson and De Ruyter (2006) claimed that customer engagement was the psychological, cognitive, and emotional levels shown by customers while interacting with a certain organization or brand. While, Bowden 
(2009) held the view that customer engagement is a mental process in which new customers develop loyalty and old customers maintain their loyalty to a certain brand. Emotionally, engagement refers to the emotional behavior involvement in certain actions towards something (Vivek et al., 2012).

In 2009, Vivek research- A Scale of Consumer Engagement- presented the definition and dimensions of customer engagement. Vivek, 2009 defined consumer engagement as "the intensity of consumer's participation and connection with the organization's offerings, and/ or organized activities." The study presented three dimensions of customer engagement which are enthusiasm reflecting the emotional element, conscious participation which presents the cognitive element, and social interaction which refers to the behavioral element.

\subsubsection{Enthusiasm}

According to Vivek (2009), the dimension of enthusiasm signifies strong excitement about the focus of engagement. Additionally, Glassman and McAfee (1990) pointed that enthusiastic individuals are willing to take risks, which make them disposed to take the initiative to avoid uncertainty and to reduce misunderstandings. Therefore, it can be argued that enthusiastic customers are disposed to reduce anxiety and uncertainty through the use of social media since it implies information explosion. Lanier \& Hampton (2008) pointed out that interactions and communication building could enable customers to get the needed information and knowledge while providing a relaxing and pleasant experience. Customers will be able to express and show themselves as they like (Kaplan \&Haenlein, 2010; Gummerus et al., 2012), especially through the use of social media platform.

\subsubsection{Conscious Participation}

Dabholkar (1990, p. 484) defined customer participation as "the degree to which the customer is involved in producing and delivering the service." Vivek, 2009 also adopted this definition to define customer participation. Jahn and Kunz (2012) analyzed three motives for participation in brand fan pages which are content-oriented, relationship-oriented, and self-oriented. Previous research indicated a close relationship between participation and perceived value in different social media platform (Cheng et al., 2009; Hollebeek, 2013). Yu et al. (2013) concluded that individuals intend to participate in social networks due to perceived value. Individuals with different cognitive participation in social media may obtain such values as acquiring news and product using skills, perceiving the relaxing and pleasant experience, as well as gaining a sense of belonging and identification (Jaakkola \& Alexander, 2014)

\subsubsection{Social interaction}

According to Vivek (2009), the dimension of social interaction represents interchange of ideas, thoughts, and feelings with other people about the engaged consumer's participation and the focus of engagement. The use of social media platforms provides customers with higher level of interactivity which can attract them to share different issues and respond quickly (Teeni, 2001). Consumers engaged in social media platforms can easily and quickly find information's about brands through e-WOM. According to Muniz \& O'guinn (2001), this quick and easy way of getting information can help individuals to know each other and become friends easily. Therefore, a stronger feeling of belonging and dependency will develop.

\subsection{Value co-creation}

Value co-creation is the process where "the consumer and the firm are intimately involved in jointly creating value that is unique to the individual consumer and sustainable to the firm" (Prahalad \& Ramaswamy, 2004a). Researches were conducted to enhance the knowledge related to value co-creation (ex. Vargo et al., 2008; Payne, Storbacka, and Frow, 2008). Dong, Evans, and Zou (2008) studied the context of service failure in value cocreation context. Wu and $\mathrm{Wu}$ (2011) used this concept to develop their service engineering process framework. Most researches focused on developing research framework and measurement instruments of value co-creation (Dong et al., 2008; Ng et al., 2010).

\subsection{Positive E-WOM}

As an Internet-based version of word of mouth, electronic word of mouth (e-WOM) has become a major source of information. With the rapid growth of the Internet, e-WOM has become a critical phenomenon. E-WOM contains both positive and negative information (Lee, Rodgers, \& Kim, 2009). Hennig-Thurau et al. (2004) 
described e-WOM as "any positive or negative statement made by potential, actual or former customers about a product or company, which is made available to a multitude of people and institutions via the Internet". Naturally, positive e-WOM increases purchase probability for decision-makers, whereas negative e-WOM has an opposite effect (Litvin et al., 2008). Positive e-WOM has an influence on product evaluation and can participate in building brands (Litvin et al., 2008). Therefore, the study will focus on positive e-WOM.

\section{Research Methodology}

\subsection{Research Model}

This study will be based on the following proposed model

Figure 1: Research Model

\subsection{Research Hypotheses}

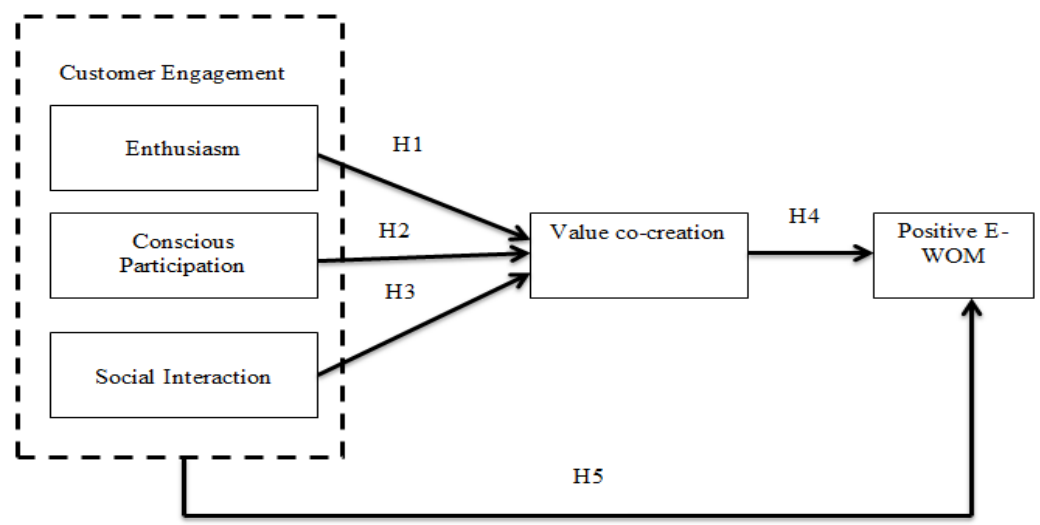

H1: Enthusiasm positively influence value co-creation

$\mathrm{H} 2$ : Conscious participation positively influence value co-creation

H3: Social interaction positively influence value co-creation

H4: Value co-creation positively influence positive e-WOM

H5: Value-co creation mediates the relationship between customer engagement on social media and positive e-WOM.

\subsection{Sampling Framework}

The target population of the study was all people who have ever engaged or searched for information through social media platform regarding international fast fashion brand in Saudi Arabia. Since no sampling frame is available, convenience sampling which is a nonrandom method will be used in order to achieve the required sample size via online survey websites.

\subsection{Instrument design}

The survey questionnaire used for this research study has been adopted from prior research. To measure customer engagement dimensions, the scale presented by Vivek (2009) was adopted. Three items were used to measure conscious participation. Four items measure enthusiasm, while social interaction was measured using three items. Nine items were adopted from Yi, Y., \& Gong, T. (2013) to measure value co-creation. Positive eWOM measurement scale was adopted from Goyette et.al (2010), which consists of four items. The initial questionnaire draft was developed in English language then the questionnaire was translated into Arabic language. Back translation was conducted to ensure face validity. As mentioned previously, since the target population of the study was people who have ever engaged or searched for information through social media platform regarding a brand.

\subsection{Data collection and analysis}


The data of this study was collected using online electronic survey. The data collection process lasted for 8 weeks. A total of 530 surveys were distributed, of which a total of 530 were returned (a response rate of $100 \%$ ). A filter question was added at the beginning of the survey, which was aimed at investigating whether the participant engages in social media activities, 301 met the required conditions and were used in the analysis. Descriptive analysis was used to find demographic characteristics of the sample, as well as Cronbach's alpha to test reliability. Convergent validity and Discriminant validity was also tested. While structural equation modeling was used to test the hypotheses.

\section{Results}

The sample included 301 respondents, 288 were Saudi and only 13 were from other nationalities. Both genders were represented in the sample while the majority of the sample was female with a percentage of $87.7 \%$ and $12.3 \%$ for male. $44.9 \%$ of the respondents were from the age group of $20-30$ years old, $27.2 \%$ were from the age group of $31-40$ years old, and $13.6 \%$ were under 20 years old. 190 of the respondents hold a Bachelor's degree while 63 finished high school. Most of the respondents were single with a percentage of $56.5 \%$ while $38.5 \%$ were married. The average household income of the respondent varied. Respondents with income ranging between SAR $20,001-30000$ account for $17.9 \%$ of the sample, while respondents with income of SAR 10,000 or less account for $23.9 \%$ of the sample, followed by respondents with income ranging between SAR $10,001-20,000$ with a percentage of $27.9 \%$, while $30.2 \%$ of the respondents' income was SAR 30,001 or more. Table. 1 illustrates the frequencies and percentages of the demographics.

Table 1. Demographic characteristics of the study sample

\begin{tabular}{|c|c|c|c|}
\hline \multirow[b]{2}{*}{ Demographics } & \multirow[b]{2}{*}{ Category } & \multicolumn{2}{|c|}{ Frequency } \\
\hline & & $n=301$ & Percent $\%$ \\
\hline \multirow[t]{2}{*}{ Gender } & Female & 264 & 87.7 \\
\hline & Male & 37 & 12.3 \\
\hline \multirow[t]{2}{*}{ Nationality } & Other & 13 & 4.3 \\
\hline & Saudi & 288 & 95.7 \\
\hline \multirow[t]{5}{*}{ Age } & $20-30$ & 135 & 44.9 \\
\hline & $31-40$ & 82 & 27.2 \\
\hline & $41-50$ & 28 & 9.3 \\
\hline & above 50 years old & 15 & 5.0 \\
\hline & Under 20 years old & 41 & 13.6 \\
\hline \multirow[t]{5}{*}{ Education } & Bachelor's degree & 190 & 63.1 \\
\hline & Doctorate degree & 3 & 1.0 \\
\hline & High school & 63 & 20.9 \\
\hline & Master degree & 38 & 12.6 \\
\hline & Other & 7 & 2.3 \\
\hline \multirow[t]{3}{*}{ Status } & Married & 116 & 38.5 \\
\hline & Other & 15 & 5.0 \\
\hline & Single & 170 & 56.5 \\
\hline
\end{tabular}




\begin{tabular}{llll}
\hline Income & 10,000 RS or less & 72 & 23.9 \\
\cline { 2 - 4 } & & & 27.9 \\
\hline $10,001-20,000$ RS & 84 & 17.9 \\
\hline $20,001-30000$ RS & 54 & 30.2 \\
\hline
\end{tabular}

Structural Equational Modeling (SEM) - AMOS- was used to analyze the data. Two steps process was followed according to Gerbing and Anderson (1988). First, the measurement model was assessed to check the reliability and validity of the model and scales. Cronbach's alpha was calculated using IBM SPSS for each measurement within a dimension to assess the internal consistency of the measurement in order to test its reliability. A cutoff value for Cronbach's alpha is acceptable when it is at least .70 (Nunnally \& Bernstein, 1994). The measures of reliability tested by Cronbach's alpha are presented in Table 2. Cronbach's alpha coefficient scores ranged from .843 to .938 across all factors. The results demonstrate a good level of internal consistency.

Table 2. Reliability test results

\begin{tabular}{ll}
\hline Factor & Cronbach's alpha \\
\hline Enthusiasm (EN) & .938 \\
\hline Conscious Participation (P) &. $\mathbf{8 4 3}$ \\
\hline Social interaction (SI) & .886 \\
\hline Value Co-Creation (VC) &. $\mathbf{9 2 6}$ \\
\hline Positive E-WOM (EW) &. $\mathbf{9 2 8}$ \\
\hline
\end{tabular}

Convergent validity was tested by looking at the estimate, all of which were significant (Bagozzi and Yi, 1988). Exploratory Factor Analysis (EFA) and Confirmatory Factor Analysis (CFA) were conducted to understand the data in hand. The AVE and the composite reliability CR for each construct are presented in Table 2 . The results presents that the convergent validity was confirmed after deleting one cross loading item from the factor value co-creation since the results of AVE are all greater than 0.5 and the results of CR are greater than 0.7 (Fornell and larcker,1981)

Table 3. Convergent validity

\begin{tabular}{lll}
\hline Factor & CR & AVE \\
\hline Value co-creation & 0.915 & 0.578 \\
\hline Enthusiasm & 0.940 & 0.796 \\
\hline Conscious Participation & 0.839 & 0.636 \\
\hline Social interaction & 0.888 & 0.726 \\
\hline Positive E-WOM & 0.928 & 0.765 \\
\hline
\end{tabular}

Discriminant validity was tested using heterotrait-monotrait ratio of correlations (HTMT). The HTMT results on Table.4 indicate that the discriminant validity was confirmed since the results are all less than 0.95 (Henseler, Ringle, and Sarstedt, 2015)

Table 4. Discriminant validity (HTMT results) 


\begin{tabular}{llllll}
\hline & Enthusiasm & $\begin{array}{l}\text { Conscious } \\
\text { Participation }\end{array}$ & $\begin{array}{l}\text { Social } \\
\text { interaction }\end{array}$ & $\begin{array}{l}\text { Value } \\
\text { creation }\end{array}$ & $\begin{array}{l}\text { co- } \\
\text { Positive } \\
\text { WOM }\end{array}$ \\
\hline Enthusiasm & - & & & \\
\hline Conscious Participation & 0.783 & - & - & - & \\
\hline Social interaction & 0.767 & 0.792 & 0.886 & - \\
\hline Value co-creation & 0.792 & 0.797 & 0.819 & 0.931 & - \\
\hline Positive E-WOM & 0.721 & 0.746 & &
\end{tabular}

The model fit was appropriate where $\mathrm{CMIN} / \mathrm{DF}=2.873, \mathrm{p}$-value $=0.00 ; \mathrm{CFI}=0.937 ; \mathrm{RMSEA}=0.079 ; \mathrm{NFI}=0.907$; $\mathrm{IFI}=0.938 ; \mathrm{GFI}=0.842$. Looking at several fit indices and taken together as suggested by the literature on global fit indices, the results indicate that the model fit is acceptable.

The structural model (Figure 1) was assessed to test the hypothesized relationships. The model fit was appropriate $(\mathrm{CMIN} / \mathrm{DF}=2.858, \mathrm{p}$-value $=0.00 ; \mathrm{CFI}=0.937 ; \mathrm{RMSEA}=0.079 ; \mathrm{NFI}=0.907 ; \mathrm{IFI}=0.937 ; \mathrm{GFI}=0.841)$. The model fit is acceptable taken several fit indices together as suggested by the literature on global fit indices.

The hypotheses testing results are presented in table 5. the results show that hypotheses $\mathrm{H} 1, \mathrm{H} 2$, and $\mathrm{H} 4$ were all accepted, while $\mathrm{H} 3$ was rejected. There is a positive association of each of Enthusiasm and Social interaction with value co-creation, while conscious participation has no association with value co-creation. There was also a positive association of Value co-creation on E-WOM.

Table.5 Hypotheses testing results.

\begin{tabular}{llllllll}
\hline \multicolumn{7}{c}{ Direct effect } & $Y<---X$ \\
\hline H1 & VC & $<---$ & EN & 0.276 & $* \star *$ & Accepted \\
\hline H2 & VC & $<---$ & SI & 0.646 & $* \star *$ & Accepted \\
\hline H3 & VC & $<---$ & P & 0.029 & $(0.745)$ & Rejected \\
\hline H4 & EW & $<---$ & VC & 0.972 & $* * *$ & Accepted \\
\hline$* *=P<0.001$ & & & &
\end{tabular}

The mediation relationships testing were presented in table 6 . The results show that value co-creation mediates the relationship between enthusiasm and positive E-WOM and between social interaction and positive E-WOM. While, value co-creation does not mediate the relationship between conscious participation and positive EWOM. Since, enthusiasm, social interaction, and conscious participation are the dimensions of customer engagement (Vivek, 2009), the results presented that value co-creation mediates the relationship between customer engagement and positive E-WOM. Therefore, H5 was accepted.

Table 6. Mediation effects

\begin{tabular}{|c|c|c|c|}
\hline & Direct effect $Y<---X$ & Indirect effect & \\
\hline EW $<---V C<---E N$ & $-1.01(\mathrm{NS})$ & $0.269 * * *$ & Full mediation \\
\hline$E W<---V C<---P$ & 0.101 (NS) & 0.028 (NS) & No mediation \\
\hline EW $<---\mathrm{VC}<---\mathrm{SI}$ & -0.038 (NS) & $0.628^{* \star *}$ & Full mediation \\
\hline EW $<---V C<---E N G$ & $-0.035(\mathrm{NS})$ & $0.898^{* * *}$ & Mediation \\
\hline
\end{tabular}

\section{Discussion}


The current study aimed to investigate the mediation effect of value-co-creation on customer engagement and positive e-WOM. The results show that value co-creation mediates the relationship between enthusiasm and positive e-WOM and between social interaction and positive E-WOM. This result explains that enthusiastic consumers socially interact and affect each other's decisions and interests by being engaged in social media activities. This result confirms previous studies such as (Muniz \& O'guinn, 2001). The results also indicated that value co-creation does not mediate the relationship between conscious participation and positive e-WOM. A possible reason for this rejection could have been the nature of participation since customer participation is "the degree to which the customer is involved in producing and delivering the service" (Dabholkar, 1990). This level of involvement is hard to obtain through social media, especially in fashion brands in which physical interaction with the product does not actually occur. Since enthusiasm, social interaction, and conscious participation are the dimensions of customer engagement (Vivek, 2009), the results presented that value co-creation mediate the relationship between customer engagement and positive e-WOM as revealed by Brodie et al. (2011) and Munjal, et al. (2019).

\section{Conclusion}

This study investigated the mediation effect of value-co-creation on customer engagement and positive eWOM. The results show that value co-creation mediates the relationship between customer engagement and positive e-WOM. This conclusion extends the scope of existing research on the relationship between value cocreation and e-WOM. Previous research points out the relationship between value co-creation and customer positive e-WOM but did not investigate this relationship with other important marketing concepts, such as customer engagement. Hence, this research contributes to the growing literature on consumer engagement in social media which is considered one of the priority research subjects in the present-day marketing field.

The current research has several implications for marketing practice. Organizations should give much concern on interacting and connecting consumers by setting up their own websites based on social media platforms, since this interaction is viewed as consumer engagement. Organizations should give more attention to how can they engage their customers in social media platforms in order to co-create customers values, which will influence the information shared through these platforms. Hence, the process of customer engagement through organizations' social media activities is an effective way of converting social platforms into a new generation of competitive marketing channels. This process will enable organizations to reinforce the value co-created by customers and guarantee customer positive E- WOM, which will build brand awareness and brand loyalty and will also increase the perceived quality of customers regarding the organization's brands.

\section{Limitation and Future research}

The sample size in the current study is relatively small. Thus, future studies are recommended to increase the sample size to figure out more consumers inserts. Besides, the adoption of non-probability sampling approach (convenience sample) reduces the generalizability of the research findings. Therefore, it is recommended that future research should replicate this research using a probability sampling technique.

The current study focused on fast fashion industry; Therefore, it is recommended that future research should replicate this study by focusing on other countries or conducting the research on other industries and comparing the results.

\section{References}

1. Bagozzi, R. P., \& Yi, Y. (1988). On the evaluation of structural equation models. Journal of the academy of marketing science, 16(1), 74-94.

2. Bowden, J. L. H. (2009). The process of customer engagement: a conceptual framework. The Journal of Marketing Theory and Practice, 17(1), 63-74

3. Brodie, R. J., Hollebeek, L. D., Jurić, B., \& Ilić, A. (2011). Customer engagement: Conceptual domain, fundamental propositions, and implications for research. Journal of Service Research, 14(3), 252-271.

4. Cheng, J. M. S., Wang, E. S. T., Lin, J. Y. C., \& Vivek, S. D. (2009). Why do customers utilize the internet as a retailing platform? A view from consumer perceived value. Asia Pacific Journal of Marketing and Logistics, 21(1), 144-160. 
5. Dabholkar, Pratibha (1990). How to Improve Perceived Service Quality by Improving Customer Participation in Development in Marketing Science, B.J. Dunlap (Ed.). Cullowhee, NC: Academy of Marketing Science.

6. Dong, B., Evans, K. R., \& Zou, S. (2008). The effects of customer participation in co-created service recovery. Journal of the Academy of Marketing Science, 36(1), 123-137.

7. Fornell, C., \& Larcker, D. F. (1981). Structural equation models with unobservable variables and measurement error: Algebra and statistics.

8. Gerbing, D. W., \& Anderson, J. C. (1988). An updated paradigm for scale development incorporating unidimensionality and its assessment. Journal of marketing research, 25(2), 186-192.

9. Gummerus, J., Liljander, V., Weman, E., \& Pihlström, M. (2012). Customer engagement in a Facebook brand community. Management Research Review, 35(9), 857-877

10. Glassman, M., \& McAfee, R. B. (1990). Enthusiasm: the missing link in leadership. SAM Advanced Management Journal, 55(3), 4-6.

11. Hajli, N., Lin, X., Featherman, M. S., \& Wang, Y. (2014). Social word of mouth: how trust develops in the market. International Journal of Market Research, 56(5), 673-689.

12. Hennig-Thurau, T., Gwinner, K. P., Walsh, G., \& Gremler, D. D. (2004). Electronic word-of-mouth via consumer-opinion platforms: What motivates consumers to articulate themselves on the Internet? Journal of Interactive Marketing, 18 (1), 38-52.

13. Henseler, J., Ringle, C. M., \& Sarstedt, M. (2015). A new criterion for assessing discriminant validity in variance-based structural equation modeling. Journal of the academy of marketing science, 43(1), $115-$ 135.

14. Hollebeek, L. D. (2013). The customer engagement/value interface: an exploratory investigation. Australasian Marketing Journal (AMJ), 21(1), 17-24.

15. Hollebeek, L. D., Glynn, M. S., \& Brodie, R. J. (2014). Consumer brand engagement in social media: conceptualization, scale development and validation. Journal of Interactive Marketing, 28(2), 149-165.

16. Jaakkola, E., \& Alexander, M. (2014). The role of customer engagement behavior in value Co-Creation a service system perspective. Journal of Service Research, 17(3), 247-261.

17. Jahn, B., \& Kunz, W. (2012). How to transform consumers into fans of your brand. Journal of Service Management, 23(3), 344-361.

18. Kaplan, A. M., \& Haenlein, M. (2010). Users of the world, unite! The challenges and opportunities of Social Media. Business Horizons, 53(1), 59-68.

19. Lanier, C., \& Hampton, R. (2008). Consumer participation and experiential marketing: understanding the relationship between co-creation and the fantasy life cycle. Advances in Consumer Research, 35(1), 4448.

20. Lee, M., Rodgers, S., \& Kim, M. (2009). Effects of valence and extremity of e-WOM on attitude toward the brand and website. Journal of Current Issues and Research in Advertising, 31(2), 1-11.

21. Litvin, S.W., Goldsmith, R.E. \& Pan, B. (2008). Electronic word-of-mouth in hospitality and tourism management. Tourism Management, 29(3), 458-68.

22. Munjal, P; Mishra, M; \& Shanker, R. (2019). The Drivers and Outcomes of Customer Engagement in Brand Communities. Journal of Management Research 19(1), 56-76. DOI: 10.5958/0974455X.2019.00005.2

23. Muniz Jr, A. M., \& O'guinn, T. C. (2001). Brand community. Journal of Consumer Research, 27(4), 412432.

24. Ng, I. C. L., Nudurupati, S. S., \& Tasker, P. (2010). Value co-creation in the delivery of outcome-based contracts for business-to-business service. AIM Research Working Paper Series.

25. Nunnally, J. C., \& Bernstein, I. H. (1994). Psychometric theory. (3rd ed.). New York: McGraw-Hill.

26. Payne, A. F., Storbacka, K., \& Frow, P. (2008). Managing the co-creation of value. Journal of the Academy of Marketing Science, 36(1), 83-96.

27. Patterson, P., Yu, T., \& De Ruyter, K. (2006). Understanding customer engagement in services. Advancing theory, maintaining relevance, proceedings of ANZMAC2006 conference, Brisbane, 4-6.

28. Prahalad, C. K., \& Ramaswamy, V. (2004a). The future of competition: Co-creating unique value with customers. Boston, MA: Harvard Business School Press. 
29. Teeni, D. (2001). Review: a cognitive-affective model of organizational communication for designing IT. MIS Quarterly, 25(2), 251-312.

30. Vargo, S. L., Maglio, P. P., \& Akaka, M. A. (2008). On value and value co-creation: A service systems and service logic perspective. European Management Journal, 26(3), 145-152.

31. Vivek, S. D., Beatty, S. E., \& Morgan, R. M. (2012). Customer engagement: Exploring customer relationships beyond purchase. Journal of Marketing Theory and Practice, 20(2), 122-146.

32. Vivek, S.D. (2009). A scale of consumer engagement (Doctoral dissertation, The University of Alabama TUSCALOOSA).

33. $\mathrm{Wu}, \mathrm{L} .-\mathrm{C} .$, \& $\mathrm{Wu}, \mathrm{L} .-\mathrm{H}$. (2011). Service engineering: An interdisciplinary framework. The Journal of Computer Information Systems, 51(2), 14-23.

34. Yu, J., Zo, H., Choi, M. K., \& Ciganek, A. P. (2013). User acceptance of location-based social networking services: an extended perspective of perceived value. Online Information Review, 37(5), 711-730.

35. Zhang, M., Guo, L., Hu, M., \& Liu, W. (2017). Influence of customer engagement with company social networks on stickiness: Mediating effect of customer value creation. International Journal of Information Management, 37(3), 229-240. 